\title{
The induction of ovulation and luteal function in seasonally anoestrous ewes treated with small-dose multiple injections of $\mathbf{G n}-\mathbf{R H}$
}

\author{
B. J. McLeod, W. Haresign* and G. E. Lamming
}

Department of Physiology and Environmental Studies and ${ }^{*}$ Department of Agriculture and Horticulture, University of Nottingham School of Agriculture Sutton Bonington, Loughborough, Leics, LE12 5RD, U.K.

\begin{abstract}
Summary. Seasonally anoestrous ewes were injected i.v. with 250,500 or $1000 \mathrm{ng}$ Gn-RH at 2-h intervals for 8 days ( 2 sheep/treatment). Each injection of 250 or 500 $\mathrm{ng} \mathrm{Gn}-\mathrm{RH}$ resulted in a transient rise in plasma $\mathrm{LH}$ concentrations. Treatment with $1000 \mathrm{ng}$ Gn-RH per injection resulted in a more sustained rise in plasma LH concentrations in 1 of 2 sheep during the early part of the treatment period. A preovulatory-type $\mathrm{LH}$ peak occurred $17-48 \mathrm{~h}$ after the start of treatment in all ewes, with a second preovulatory-type peak $106-133 \mathrm{~h}$ later in those ewes receiving 500 or $1000 \mathrm{ng}$ Gn-RH per injection. Ovulation, with subsequent normal luteal function, occurred in all sheep. However, the rise in plasma progesterone concentrations appeared to be delayed in those ewes treated with 500 or $1000 \mathrm{ng}$ Gn-RH compared to ewes treated with $250 \mathrm{ng} \mathrm{Gn}-\mathrm{RH}$. These data suggest that the absence of ovulation during seasonal anoestrus is due to an inadequate pattern of episodic LH secretion.
\end{abstract}

\section{Introduction}

Administration of a single injection of 150 or $300 \mu \mathrm{g}$ synthetic $\mathrm{Gn}-\mathrm{RH}$ induced a preovulatory-type LH surge and ovulation in the majority of seasonally anoestrous ewes, even though the LH surge was only about $25 \%$ of the magnitude of the natural peak at oestrus (Foster \& Crighton, 1973, 1974; Crighton, Foster, Haresign \& Scott, 1975). However, luteal function, as assessed by peripheral plasma progesterone concentrations, was completely absent in most animals (Crighton, Foster, Haresign, Haynes \& Lamming, 1973; Haresign, Foster, Haynes, Crighton \& Lamming, 1975). Adminstration of the same total dose of Gn-RH as a series of 5 injections (Crighton et al., 1975) or following pre-treatment with oestradiol benzoate (Haresign \& Lamming, 1978) resulted in a much greater induced preovulatory-type LH release, but did not increase the incidence of normal luteal function. Ovulation with subsequent luteal function was, however, produced by treating ewes with PMSG $24 \mathrm{~h}$ before injection of Gn-RH, prompting the suggestion that the lack of luteal function in ewes treated with $\mathrm{Gn}-\mathrm{RH}$ alone was due to inadequate follicular development before the induction of ovulation (Haresign \& Lamming, 1978).

The natural pattern of $\mathrm{LH}$ secretion in sheep is episodic in nature, basal levels of $0 \cdot 1-2 \cdot 0$ $\mathrm{ng} / \mathrm{ml}$ being interspersed with small short-lived episodes, each of $5-15 \mathrm{ng} / \mathrm{ml}$ and lasting about 30 min. During the luteal phase of the oestrous cycle and during seasonal anoestrus, these $\mathrm{LH}$ episodes occur irregularly at 3 to 12-h intervals (Baird, 1978; Baird, Swanston \& Scaramuzzi, 1976; Scaramuzzi \& Baird, 1977; Yuthasastrakosol, Palmer \& Howland, 1977; B. R. Friman \& 
W. Haresign, unpublished data), but following regression of the corpus luteum their frequency increases until they occur at the rate of about one per 1-2 $\mathrm{h}$ immediately before the preovulatory LH peak (Yuthasastrakosol et al., 1977; Baird, 1978). Each LH episode is followed by an increase in ovarian vein levels of oestradiol and this, together with the parallel increases in basal secretion of both $\mathrm{LH}$ and oestradiol during the follicular phase of the cycle, has led to the suggestion that the final stages of follicle development may be controlled by tonic LH secretion (Baird, 1978).

The purpose of the present study was to investigate whether small doses of $\mathrm{Gn}-\mathrm{RH}$, administered at 2-h intervals in an attempt to mimic the pattern of the LH secretion which occurs during the follicular phase of the oestrous cycle, were capable of inducing follicle development, ovulation and normal luteal function in seasonally anoestrous ewes. The doses were selected on the basis that they would induce small $\mathrm{LH}$ surges of $10-15 \mathrm{ng} / \mathrm{ml}$ plasma rather than the preovulatory-type LH peaks $(60-200 \mathrm{ng} / \mathrm{ml})$ which result from injections of 150 or 300 $\mu \mathrm{g} \mathrm{Gn-RH.}$

\section{Materials and Methods}

\section{Animals and experimental design}

Eight 5-year-old seasonally anoestrous Clun Forest ewes with an average liveweight of 50.5 $\mathrm{kg}$ were treated over an 8-day period in early August 1979. All ewes were housed in individual pens under conditions of natural daylength and temperature, and fed a diet of 'indoor' ewe concentrates and hay, with water always available. Injections of 250,500 or $1000 \mathrm{ng}$ synthetic Gn-RH (Lutal: Fabwerke Hoechst AG, Frankfurt, West Germany) in $2 \mathrm{ml}$ sterile saline $(9 \mathrm{~g}$ $\mathrm{NaCl} / \mathrm{l}$ ) were each given to 2 ewes via an indwelling jugular vein catheter at 2-h intervals for an 8-day treatment period. The 2 control ewes received saline alone.

Blood samples $(10 \mathrm{ml})$ for progesterone determination were collected daily by jugular venepuncture from 2 days before until 20 days after treatment. Blood samples $(2 \mathrm{ml})$ for $\mathrm{LH}$ determination were collected via the indwelling catheter at 15 -min intervals from $12 \mathrm{~h}$ before until $24 \mathrm{~h}$ after the first $\mathrm{Gn}-\mathrm{RH}$ injection. A further 24 -h period of 15 -min blood sampling was carried out on Day 4 of the treatment. At other times during the treatment period blood samples for $\mathrm{LH}$ determination were taken at 2-h intervals immediately before the $\mathrm{Gn}-\mathrm{RH}$ injection.

All ewes underwent laparoscopy to assess ovarian activity 2 days before and 4 days after the period of hormone treatment.

\section{Progesterone assay}

Plasma progesterone concentrations were determined by the radioimmunoassay method of Haresign et al. (1975). The assay showed negligible cross-reaction with other steroids and, within this study, the limit of sensitivity of the assay was $37 \mathrm{pg} /$ tube $(0.1 \mathrm{ng} / \mathrm{ml})$, the inter- and intra-assay coefficients of variation were 9.6 and $4.6 \%$ respectively, and the mean extraction efficiency was $71 \cdot 8 \pm 3.4 \%$.

\section{LH assay}

Plasma LH concentrations were measured using the specific double-antibody radioimmunoassay technique described by Foster \& Crighton (1974) with the following modifications. The volumes of plasma and diluent used were $100 \mu \mathrm{l}$ and $150 \mu \mathrm{l}$ respectively, and the first antibody was used at an initial working dilution of 1:105000. Bovine serum albumin $(1 \mathrm{~g} / \mathrm{l})$ was substituted for egg albumin in the assay buffer to overcome problems with precipitation, and incubation with the second antibody was increased from 24 and $48 \mathrm{~h}$. These procedures changed 
the limit of sensitivity of the assay to $0.3 \mathrm{ng} \mathrm{NIH-LH-S17} \mathrm{equiv./ml.} \mathrm{The} \mathrm{inter-} \mathrm{and} \mathrm{intra-assay}$ coefficients of variation within this study were $11.1 \%$ and $9.6 \%$ respectively.

\section{Results}

Ovarian activity

Laparoscopic observations 2 days before treatment showed that all ewes had reproductive tracts typical of those found during seasonal anoestrus, with little or no evidence of follicular development. At the second laparoscopy 4 days after the end of the treatment period, all Gn-RH-treated ewes had ovulated, and the resultant corpora lutea appeared macroscopically normal. The individual ovulation rates are shown in Table 1. Neither of the control ewes, receiving saline alone, showed any evidence of ovarian development.

Table 1. Time of preovulatory LH peaks and ovulation rates in seasonally anoestrous ewes treated with injections of Gn-RH every $2 \mathrm{~h}$

\begin{tabular}{ccccc}
\hline Ewe & $\begin{array}{c}\text { Gn-RH dose } \\
\text { (ng/inj) }\end{array}$ & $\begin{array}{c}\text { Interval from 1st injection } \\
\text { to onset of LH peak (h) }\end{array}$ & $\begin{array}{c}\text { Duration of } \\
\text { LH peak (h) }\end{array}$ & $\begin{array}{c}\text { Ovulation } \\
\text { rate }\end{array}$ \\
\hline 31 & 250 & 22 & 14 & 2 \\
32 & 250 & 32 & 14 & 2 \\
33 & 500 & 32 & 12 & 3 \\
& & 152 & 16 & \\
34 & 500 & 40 & 8 & 3 \\
& & 148 & 10 & \\
35 & 1000 & 48 & 10 & 2 \\
36 & 1000 & 154 & 12 & \\
& & 17 & 10 & 2 \\
37 & 0 & 150 & - & - \\
38 & 0 & - & - & - \\
\hline
\end{tabular}

\section{LH concentrations}

A rise in $\mathrm{LH}$ concentrations was defined as an episode if (i) there was an increase of at least $50 \%$ above the preceding baseline value, (ii) there were at least two points between the peak value and the succeeding trough or baseline, and (iii) the rate of decline in concentrations after the peak was no greater than that allowed by the half-life of the hormone. As shown in Text-fig. 1, during the $12 \mathrm{~h}$ before the first $\mathrm{Gn}-\mathrm{RH}$ injection, plasma $\mathrm{LH}$ concentrations were basal $(0.5-2.0$ $\mathrm{ng} / \mathrm{ml}$ ) for most of the time and included no more than a single, small LH episode (mean maximum concentration $6.8 \pm 0.7 \mathrm{ng} / \mathrm{ml}$, range $5.2-14.7 \mathrm{ng} / \mathrm{ml}$ ). Each $\mathrm{Gn}-\mathrm{RH}$ injection induced an immediate, but transient, rise in plasma LH concentrations and, in all Gn-RH-treated ewes, this response was greater to the initial 3 or 4 than to subsequent injections.

The 24-h period of 15-min blood collection carried out on Day 4 of the treatment period indicated a pattern of plasma $\mathrm{LH}$ concentrations in response to $\mathrm{Gn}-\mathrm{RH}$ injections similar to that found during the first $24 \mathrm{~h}$ of treatment, except that, even at the $1000 \mathrm{ng}$ dose level, $\mathrm{LH}$ concentrations returned to basal values between injections. Typical examples are shown in Text-fig. 2.

All Gn-RH-treated ewes showed a preovulatory-type LH peak (maximum concentration 68-145 $\mathrm{ng} / \mathrm{ml}$ and of $8-16 \mathrm{~h}$ duration) $17-48 \mathrm{~h}$ after the start of treatment, with a further preovulatory-type $\mathrm{LH}$ peak $106-133 \mathrm{~h}$ later in those ewes receiving 500 or $1000 \mathrm{ng} \mathrm{Gn}-\mathrm{RH}$ per injection (Table 1).

With the exception of occasional episodes, the LH concentrations in the control ewes remained basal throughout the entire treatment period (Text-fig. 1d). 

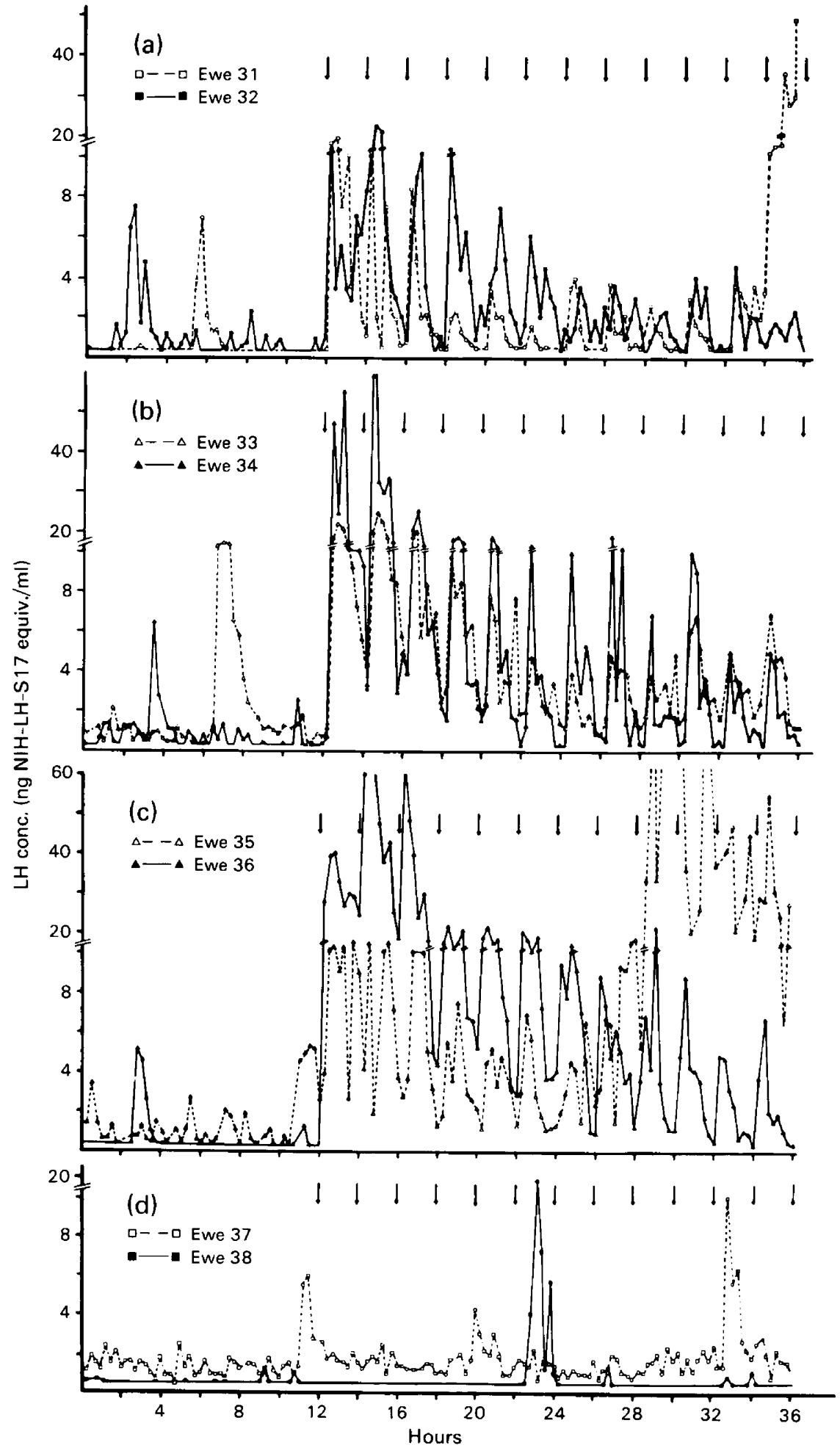

Text-fig. 1. Plasma LH concentrations in ewes in response to injections every $2 \mathrm{~h}$ of (a) $250 \mathrm{ng}$, (b) $500 \mathrm{ng}$ or (c) $1000 \mathrm{ng} \mathrm{Gn-RH}$ per injection or (d) saline only. Blood samples were collected at 15 -min intervals from $12 \mathrm{~h}$ before until $24 \mathrm{~h}$ after the start of treatment. The time of each $\mathrm{Gm}-\mathrm{RH}$ injection is indicted by arrows. 


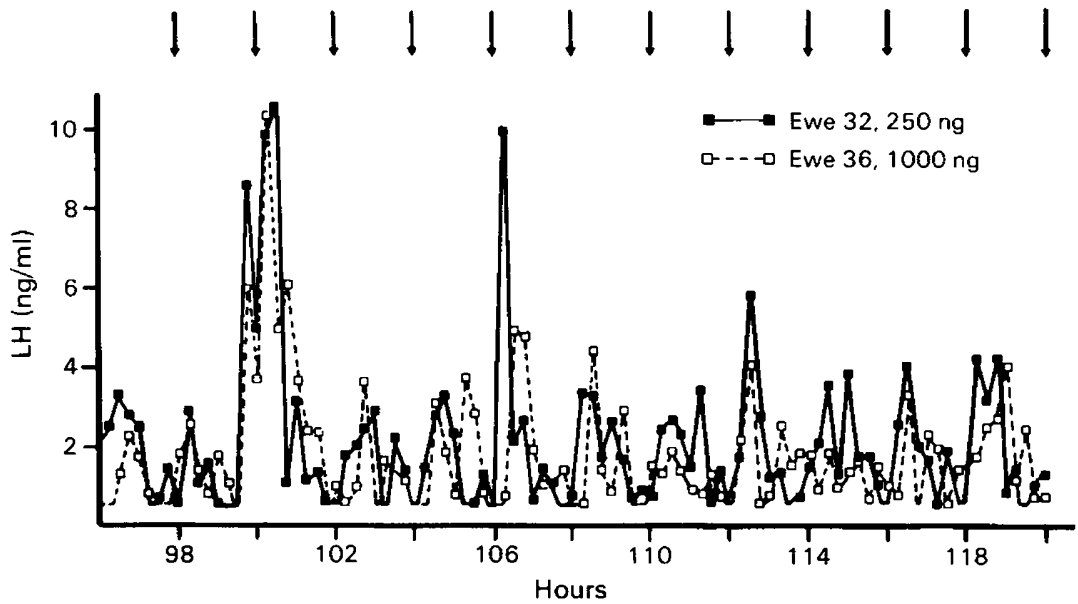

Text-fig. 2. Plasma LH concentrations in response to injections of Gn-RH every $2 \mathrm{~h}$ on Day 4 of the treatment period. Blood samples were collected at 15 -min intervals and the arrows indicate the time of each $\mathrm{Gn}-\mathrm{RH}$ injection.

\section{Progesterone concentrations}

In all Gn-RH-treated ewes the post-ovulatory pattern of plasma progesterone concentrations was similar to that found during the normal oestrous cycle. Values rose from basal $(<0.5 \mathrm{ng} / \mathrm{ml})$ to $>2.5 \mathrm{ng} / \mathrm{ml}$ (maximum concentrations $3.3 \pm 0.2 \mathrm{ng} / \mathrm{ml}$ ), and remained elevated for $10-12$ days (Text-fig. 3). However, this rise started 3-4 days later in ewes treated with 500 or $1000 \mathrm{ng}$ $\mathrm{Gn}-\mathrm{RH}$ per injection than it did in ewes treated with $250 \mathrm{ng}$ per injection.

Plasma progesterone concentrations remained basal throughout the sampling period in ewes treated with saline alone (Text-fig. 3).
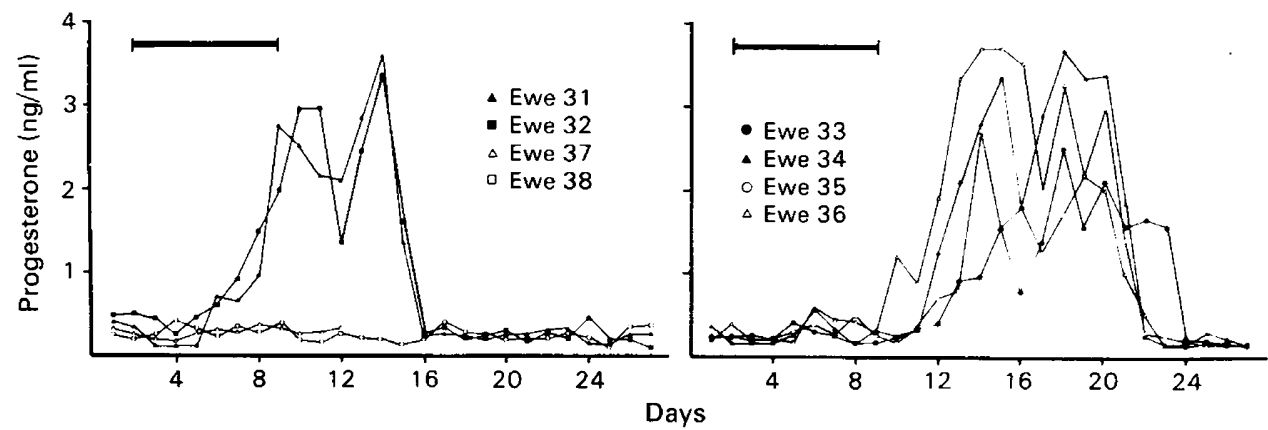

Text-fig. 3. Peripheral plasma progesterone concentrations in saline-treated control ewes (Ewes 37 and 38) or ewes treated with $250 \mathrm{ng}$ (Ewes 31 and 32), $500 \mathrm{ng}$ (Ewes 33 and 34) or $1000 \mathrm{ng}$ (Ewes 35 and 36) of Gn-RH at 2-h intervals during seasonal anoestrus. The treatment period is indicated by the horizontal bar.

\section{Discussion}

The ability of single i.v. injections of 150 or $300 \mu \mathrm{g} \mathrm{Gn}-\mathrm{RH}$ to induce ovulation in seasonally anoestrous ewes has been widely reported. However, following this type of treatment the induced ovulation rate never exceeded one, even in breeds that consistently produce multiple ovulations at natural oestrus (Crighton et al., 1973; Haresign et al., 1975). In contrast, repeated injections 
of low doses of Gn-RH as used in this present study induced multiple ovulations and normal luteal function in all 6 treated ewes.

A single injection of 150 or $300 \mu \mathrm{g} \mathrm{Gn-RH}$ to seasonally anoestrous ewes results in an immediate preovulatory-type LH surge which is similar to, but significantly smaller than, that at a natural oestrus (Crighton, Scott \& Foster, 1974). In contrast, the levels of Gn-RH used in the present study were insufficient to induce such a surge at the two lower dose levels used, but rather resulted in an extended period of episodic LH secretion. The preovulatory-type LH peaks which did occur 17-48 h after the start of treatment did not appear to be directly related to the injections of Gn-RH but, more likely, were the result of endogenous endocrine responses to this period of elevated gonadotrophin output. Although plasma oestrogen concentrations were not measured in this experiment it is probable that the preovulatory LH peaks resulted from the positive feedback effects of high levels of oestrogen on the hypothalamo-pituitary axis (Karsch, Legan, Ryan \& Foster, 1977), particularly since similar treatments result in oestrus in seasonally anoestrous ewes which are pretreated with progesterone (B. J. McLeod \& W. Haresign, unpublished data).

The presence of a second preovulatory-type LH surge in 4 of the ewes in this trial suggests that, in the absence of a rise in progesterone concentrations resulting from the first preovulatory LH surge in these ewes, the ovarian-hypothalamo-pituitary axis continued to respond with a periodicity of 106-133 h (Table 1). The negative feedback effects of the earlier elevation in plasma progesterone in response to the first LH peak in Ewes 31 and 32 would account for the absence of a second preovulatory peak in these animals as shown by Karsch et al. (1977).

It has been reported that plasma progesterone concentrations rise approximately 4 days after the preovulatory LH peak in cyclic ewes (Thorburn, Bassett \& Smith, 1969; Yuthasastrakosol et al., 1973). This would suggest that the increased progesterone concentrations noted in this experiment arose from corpora lutea resulting from the first preovulatory LH peak in Ewes 31 and 32, and from the second pre-ovulatory peak in Ewes 33-36. The reasons for this are not clear although it is possibly related to the different dose-dependent patterns of episodic $\mathrm{LH}$ secretion before the first preovulatory-type LH surge. It is notable that the induced LH episodes on Day 4 of treatment were very similar and not apparently related to dose. It is not clear whether ovulation occurred in response to the first preovulatory LH peak in Ewes 33-36 because no laparoscopic examination was made until 4 days after the end of the treatment period, and at that time the corpora lutea of all 6 treated ewes were very similar in appearance.

The high incidence of multiple ovulation and the endogenous initiation of preovulatory $\mathrm{LH}$ peaks in treated ewes support the suggestion of a possible direct role for tonic LH secretion in stimulating the final stages of follicle development and oestrogen synthesis in the ewe. A similar close relationship between episodic LH secretion and reproductive activity has been shown by the ability of repeated injections of small doses of $\mathrm{LH}$ to induce ovulation in prepubertal ewe lambs (Ryan \& Foster, 1980). The role of changes in FSH concentrations in the responses noted cannot be ignored. Unfortunately, FSH was not measured in this experiment but similar work in the ram has shown that FSH is very slow to respond to multiple injections of low doses of Gn-RH (Lincoln, 1979). This would suggest that the induction of ovulation and luteal function in at least the 2 ewes treated with $250 \mathrm{ng} \mathrm{Gn}-\mathrm{RH}$ per injection was primarily due to induced changes in $\mathrm{LH}$ rather than FSH secretion.

This hormone treatment regimen has also been shown to induce reproductive activity during post-partum anoestrus in beef cows (Riley, Peters \& Lamming, 1981), to induce menstrual cycles in prepubertal monkey (Wildt, Marshall \& Knobil, 1980) and hypogonadotrophic women (Crowley \& McArthur, 1980; Leyendecker, Wildt \& Hansmann, 1980) and to restore sexual activity to seasonally anoestrous rams (Lincoln, 1979). In addition, these data suggest that the absence of ovulation in seasonally anoestrous ewes is due to an inadequate pattern of episodic LH secretion. Correction of this inadequacy with small-dose multiple injections of Gn-RH resulted in ovulation and normal luteal function in all ewes. 
We thank Hoechst Pharmaceuticals for finanacial support and supplies of synthetic Gn-RH; The National Institutes of Health for standard LH; and Dr B. J. A. Furr for the progesterone antiserum.

\section{References}

Baird, D.T. (1978) Pulsatile secretion of LH and ovarian estradiol during the follicular phase of the sheep estrous cycle. Biol. Reprod. 18, 359-364.

Baird, D.T., Swanston, I. \& Scaramuzzi, R.J. (1976) Pulsatile release of $\mathrm{LH}$ and secretion of ovarian steroids in sheep during the luteal phase of the estrous cycle. Endocrinology 98, 1490-1496.

Crighton, D.B., Foster, J.P., Haresign, W., Haynes, N.B. \& Lamming, G.E. (1973) The effects of a synthetic preparation of gonadotrophin releasing factor on pituitary and ovarian function in anoestrous ewes. $J$. Physiol., Lond. 231, 98P-99P, Abstr.

Crighton, D.B., Scott, S.A. \& Foster, J.P. (1974) An attempt to simulate by injection of luteinizing hormone releasing hormone in the anoestrous sheep, the pattern of release observed at oestrus and the effects of this on luteinizing hormone release. $J$. Endocr. 61, lxiii-lxiv, Abstr.

Crighton, D.B., Foster, J.P., Haresign, W. \& Scott, S.A. (1975) Plasma LH and progesterone levels after single or multiple injections of synthetic LH-RH in anoestrous ewes and comparison with levels during the oestrous cycle. J. Reprod. Fert. 44, 121-124.

Crowley, W.F. \& McArthur, J.W. (1980) Simulation of the normal menstrual cycle in Kallman's Syndrome by pulsatile administration of luteinizing hormonereleasing hormone (LH-RH). J. clin. Endocr. Metab. 51, 173-175.

Foster, J.P. \& Crighton, D.B. (1973) Preliminary observations on the administration of a synthetic preparation of gonadotrophin-releasing factor to cyclic and anoestrous ewes. J. Endocr. 57, xxv, Abstr.

Foster, J.P. \& Crighton, D.B. (1974) Luteinizing hormone (LH) release after single injections of synthetic LH-releasing hormone (LH-RH) in the ewe at three different reproductive stages and comparison with natural $\mathrm{LH}$ release at oestrus. Theriogenology $\mathbf{2}$, $87-100$.

Haresign, W. \& Lamming, G.E. (1978) Comparison of $\mathrm{LH}$ release and luteal function in cyclic and $\mathrm{LH}-\mathrm{RH}$ treated anoestrous ewes pre-treated with PMSG or oestrogen. J. Reprod. Fert. 52, 349-353.

Haresign, W., Foster, J.P., Haynes, N.B., Crighton, D.B.
\& Lamming, G.E. (1975) Progesterone levels following treatment of seasonally anoestrous ewes with synthetic LH-releasing hormone. J. Reprod. Fert. 43, 269-279.

Karsch, F.J., Legan, S.J., Ryan, K.D. \& Foster, D.L. (1977) The feedback effects of ovarian steroids on gonadotrophin secretion. In Control of Ovulation, pp. 29-48. Eds D. B. Crighton, G. R. Foxcroft, N. B. Haynes \& G. E. Lamming. Butterworths, London.

Leyendecker, G., Wildt, L. \& Hansmann, M. (1980) Pregnancies following chronic intermittent (pulsatile) administration of $\mathrm{Gn}-\mathrm{RH}$ by means of a portable pump ("Zyklomat") - a new approach to the treatment of infertility in hypothalamic amenorrhea. $J$. clin. Endocr. Metab. 51, 1214-1216.

Lincoln, G.A. (1979) Use of a pulsed infusion of luteinizing hormone-releasing hormone to mimic seasonally induced endocrine changes in the ram. $J$. Endocr. 83, 251-260.

Riley, G.M., Peters, A.R. \& Lamming, G.E. (1981) Induction of pulsatile $\mathrm{LH}$ release and ovulation in post-partum acyclic beef cows by repeated small doses of Gn-RH. J. Reprod. Fert. 63, 559-565.

Ryan, K.D. \& Foster, D.L. (1980) Neuroendocrine mechanisms involved in the onset of puberty in the female: concepts derived from the lamb. Fedn Proc. Fedn Am. Socs exp. Biol. 39, 2372-2377.

Scaramuzzi, R.J. \& Baird, D.T. (1977) Pulsatile release of luteinizing hormone and the secretion of ovarian steroids in sheep during anestrus. Endocrinology 101, 1801-1806.

Thorburn, G.D., Bassett, J.M. \& Smith, I.D. (1969) Progesterone concentration in plasma of the sheep during the oestrous cycle. J. Endocr. 45, 459-469.

Wildt, L., Marshall, G. \& Knobil, E. (1980) Experimental induction of puberty in the infantile female Rhesus monkey. Science, N.Y. 207, 1373-1375.

Yuthasastrakosol, P., Palmer, W.M. \& Howland, B.E. (1973) Hormone levels in the anestrous and cycling ewe. J. Anim. Sci. 37, 334.

Yuthasastrakosol, P., Palmer, W.M. \& Howland, B.E. (1977) Release of LH in anoestrous and cyclic ewes. J. Reprod. Fert. 50, 319-321.

Received 17 April 1981 